\title{
Knowledge of cholera and its prevention amongst urban residents of a district in Abuja: The pivotal role of health education
}

\author{
*Anetor, G.O. ${ }^{1}$, Abraham, F. ${ }^{2}$
}

\begin{abstract}
Objectives: Cholera is endemic in many Africa countries including Nigeria, where it is still endemic despite all the control measures put in place. It is still a disease of public health importance. The northern parts of Nigeria been implicated in the recent spike in cholera cases in Nigeria. Durumi, one of the communities in the Federal Capital Territory (FCT) has been observed to have cases of cholera in recent times but with paucity of data on the occurrence of the disease in Durumi. This study examined the knowledge of cholera and its prevention amongst the residents of Durumi to get baseline information and ascertain the role of health education in curtailing cholera in the community.
\end{abstract}

Methods: A Descriptive (cross-sectional) survey design. Multistage sampling was used to select 360 participants (171 females and 159 males) and a self-developed validated questionnaire was used to collect data. Data was analyzed using descriptive statistics of frequency counts and percentages and inferential statistics of Chi-square to test the hypotheses at 0.05 significant levels.

Results: Knowledge of cholera significant (p-value $.000<0.05$ ); age group below 50 years contributed higher percentage scores than those above 50 years old. Awareness of preventive measures to cholera also significant ( $\mathrm{p}$-value $.000<0.05$ ); the age group below 50 years contributed higher scores than those above 50 years old. Findings suggest insufficient knowledge and awareness of preventive measures of cholera for age $>50$ years.

Conclusion: Durumi residents appear to have adequate knowledge and awareness of cholera preventive measures. Targeted health education may be employed to prevent cholera in Durumi.

Keywords: Cholera, knowledge, prevention, Abuja, health education

*Corresponding Author

Anetor, G.O. (PhD)

ORCID-ID: http://orcid.org/0000-0002-

Email: yahuanet@yahoo.com

'Human Kinetics and Health Education Department, Faculty of Education, National Open University of Nigeria, Abuja, Nigeria

${ }^{2}$ Public Health Science Department, Faculty of Health Sciences, National Open University of Nigeria, Abuja, Nigeria 


\title{
Connaissance du choléra et de sa prévention chez les résidents urbains d'un quartier d'Abuja: Le rôle significatif de l'éducation en santé
}

\author{
*Anetor, G.O. ${ }^{1}$, Abraham, F. ${ }^{2}$
}

\begin{abstract}
Résumé
Objectifs: Le choléra est endémique dans de nombreux pays africains dont le Nigéria, où il est toujours endémique malgré toutes les mesures de contrôle mises en place. Il s'agit toujours d'une maladie d'importance pour la santé publique. Les parties nord du Nigéria ont été impliquées dans la récente flambée de cas de choléra au Nigéria. Durumi, l'une des communautés du Territoire de la capitale fédérale (TCF), a récemment été témoin de cas de choléra, mais avec peu de données sur l'occurrence de la maladie à Durumi. Cette étude a examiné les connaissances sur le choléra et sa prévention parmi les habitants de Durumi pour obtenir des informations de référence et déterminer le rôle de l'éducation sanitaire dans la lutte contre le choléra dans la communauté.
\end{abstract}

Méthodes: Un plan d'enquête descriptif (transversal). Un échantillonnage à plusieurs degrés a été utilisé pour sélectionner 360 participants (171 femmes et 159 hommes) et un questionnaire validé autodéveloppé a été utilisé pour collecter les données. Les données ont été analysées à l'aide de statistiques descriptives des comptes de fréquence et des pourcentages et des statistiques inférentielles du chi carré pour tester les hypothèses à 0,05 niveaux significatifs.

Résultats: Connaissance du choléra significative (valeur p .000<0,05); le groupe d'âge de moins de 50 ans a contribué à des scores en pourcentage plus élevés que ceux de plus de 50 ans. La sensibilisation aux mesures préventives contre le choléra est également importante (valeur de p .000<0,05); le groupe d'âge de moins de 50 ans a contribué des scores plus élevés que ceux de plus de 50 ans. Les résultats suggèrent une connaissance et une sensibilisation insuffisantes des mesures préventives du choléra pour l'âge $>50$ ans.

Conclusion: Les résidents de Durumi semblent avoir une connaissance et une sensibilisation adéquates des mesures de prévention du choléra. Une éducation sanitaire ciblée peut être utilisée pour prévenir le choléra à Durumi.

Mots-clés: Choléra, connaissance, prévention, Abuja, éducation sanitaire

*Corresponding Author

Anetor, G.O. (PhD)

ORCID-ID: http://orcid.org/0000-0002-

Email: yahuanet@yahoo.com

${ }^{1}$ Human Kinetics and Health Education Department, Faculty of Education, National Open University of Nigeria, Abuja, Nigeria

${ }^{2}$ Public Health Science Department, Faculty of Health Sciences, National Open University of Nigeria, Abuja, Nigeria

Research Journal of Health Sciences subscribed to terms and conditions of Open Access publication. Articles are distributed under the terms of Creative Commons Licence (CC BY-NC-ND 4.0). (http://creativecommons.org/licences/by-nc-nd/4.0).

http://dx.doi.org/10.4314/rejhs.v8i1.6 


\section{INTRODUCTION}

Cholera is an extremely virulent disease with its transmission closely linked to inadequate access to clean portable water, poor food handling and poor environmental sanitation. The disease is caused by contamination of food or water by the bacterium Vibrio cholera. There are only two serogroups of $V$. cholerae (O1 and O139) that cause outbreaks out of many serogroups that exist. The infection is characterized by severe bouts of acute diarrhea (rice-water stool) and vomiting, and affects people of all ages. According to the World Health Organization (WHO) (1) and other researchers (2), pointed out that there are estimated cholera cases ranging from 1.3 to 4.0 million, and 21000 to 143000 deaths worldwide annually. Cholera is a disease of public health concern globally and it is an indicator of inequity and lack of social development $(1,3)$. Many countries in the world are affected by cholera; Pakistan, Somalia, Sudan, Vietnam, Haiti, India, Bangladesh and other Asia and African countries (4). Cholera is particularly endemic in many African counties (4). Devastating epidemics of cholera have occurred in Angola, Ethiopia, Zimbabwe, Ghana, and Nigeria among others $(4,5)$. Ali et al (6) reported that most cholera infections are not detected, but large outbreaks of cholera occur in developing countries. They pointed out that industrialized countries have seen practically no cholera cases for over a century because of their good water and sewage treatment infrastructure.

The number of cholera cases is possibly much higher than what is reported to the World Health Organization because of differences in case definitions, authorities reluctance to acknowledge and report cholera, hospitals surveillance systems may not be adequate, lack of effective diagnostic tests and similarities in clinical presentation of cholera with other acute watery diarrhoea (AWD) diseases (7). Within Africa, half of all cases between 1970 and 2011 were notified from only seven counties; Angola, Democratic Republic of Congo, Mozambique, Nigeria, Somalia, Tanzania and South Africa (8, 9). In developing countries, it is difficult to calculate the exact number of cases as many go unreported due to socio-political concerns that an outbreak may have a negative impact on tourism to the country (4).

In Nigeria, Cholera remains endemic and increase in morbidity and mortality is high in the northern part of the country probably due to many people using water from open wells in northern Nigerian (10). It is one of the infectious diseases that remains a major health burden in Nigeria and it is a growing threat, especially for those most vulnerable. The most vulnerable include those without clean water, with lack of access to soap and sanitation, the displaced, the food insecure and the impoverished they are most at risk of being infected, they become very ill and likely to die (11).The northern part of Nigeria including some parts of the FCT have been implicated in presenting with cholera in recent times $(9,12)$. In the last quarter of 2009, it was speculated that more than 260 people died of cholera in four northern states with over 96 people in Maidugari, Biu, Gwoza, Dikwa and Jere council areas of Bauchi state (8). In another study carried out in 2014 in the Federal Capital Territory (FCT) Abuja, Gomani, Kwali Local Government Area was reported to have a high morbidity and mortality of cholera (13). It was also reported in 2017 that Borno North-eastern part as well as Kwara, North-Central parts of the country had their episodes of cholera outbreaks and many lives were lost $(13,12)$. It was also reported that cholera cases are still ravaging eight States including Adamawa, Bauchi, Kano, Katsina, Zamfara, Kogi, Plateau and Kaduna, although, there appears to be a relative decline in the number of new cases $(13,12)$.

The persistence of cholera in Nigeria has been attributed by many studies to disruption in public sanitation services, landslides and floods also contribute to outbreak by disrupting the normal balance of nature, open flow of sewage water within the surrounding, food and water supplies contaminated by parasites and bacteria when essential system like those for water and sewage are destroyed, lack of resources, infrastructure and disaster preparedness system among others $(4,8,13,14)$. Generally, it is believed that cholera occurs in most countries in the dry season, but in Nigeria where it is endemic, it occurs in both rainy and dry seasons, although the burden of cholera tends to increase during beginning of rainy and dry seasons (15). However, it is still being reported in many studies that the affected areas with cholera in the country lacked good water supply, have poor sanitation, suffer from overcrowdedness, poor public health education, lack of good medical infrastructure among others $(8,13,15,16$, ).

Dan-Nwafor et al (16) revealed that in a study on cholera carried out in a district in North central Nigeria, the people lacked sufficient knowledge and control awareness of cholera. Denue and colleagues (13) also reported that despite the huge public health impact of cholera, 
there is a dearth of information about this preventable disease in Nigeria especially the northern part as most outbreaks are either underreported or not thoroughly investigated. Elimian et al (2) also pointed out that there is dearth of evidence of knowledge and control of cholera in Nigeria.

This study was carried out in Durumi which is a prominent area in the Federal Capital Territory (FCT), Abuja. The study aimed to examine the knowledge of cholera and its preventive measures among the residents of Durumi district in order to identify any lapses among the people that may make them predisposed to cholera outbreak, so that necessary interventions and recommendations may be proffered to prevent an upsurge of the disease. This is considered an important step to take, because the knowledge and attitude of the people living in a particular community is important in the prevention and control of cholera.

\section{Two questions were answered:}

1. Are Durumi residents generally knowledgeable about cholera?

2. Is there an overall awareness of cholera among Durumi residents?

Two hypotheses were tested:

1. There is no significant difference in the percentage general knowledge score of cholera between the different age groups.

2. There is no significant difference in the percentage awareness of preventive measures score between the different age groups.

\section{MATERIALS AND METHODS Study Area}

Abuja is the federal Capital Territory (FCT) and is located in the North central part of the country with many people from the north and other parts of the country residing in the FCT. Durumi, a community in the FCT, has been observed to have some predisposing factors that may make them easily susceptible to cholera outbreak; especially poor environmental sanitation and inadequate water supply. The researcher also observed that the community had some suspected cases of cholera that have been underreported in 2018.

Durumi district is one of the fastest growing settlements in the city and still developing. It is located southwest of Abuja and is bordered by Garki Districts I and II to the northeast. Its borders are the Oladipo Diya Road to the southwest, the Nnamdi Azikiwe Express
Way to the northeast, and Ahmadu Bello Way to the southeast. The population of Durumi according to 2018 population estimate (adult and children) was twelve thousand nine hundred and sixty six $(12,966)(17,18)$. Among the predominant tribes are the Gwaris, Hausa, Igbo, Yoruba, Igala, Tiv and Idoma. The social amenities within the community include; Government primary school, junior secondary school, private clinic, bore holes, private nursery and primary schools, Churches, Mosque and River. Their major occupation is petty trading and farming while some are civil servants.

\section{Design and Population}

Descriptive (cross-sectional) survey design was employed to carry out the study. The study population was made up of all males and females who were eighteen years and above and has been resident at Durumi District Abuja for a minimum of one year.

\section{Sampling and Data Collection Method}

The community leaders in the areas of interest were contacted and a date and venue was chosen for the selection of participants for the study. Multistage sampling technique was used for the data collection. The researcher determined to use $3 \%$ of the available population $(12,000$ were 18 years and above); which gave 360 and this was considered relatively adequate to the calculated sample size of 387 using Yamane's formula

$$
\mathrm{n}=\frac{\mathrm{N}}{(1+\mathrm{Ne}) 2}
$$

Durumi community has pre-existing strata (three strata) which was used for the study as follows: Durumi 1 had 5000 residents; Durumi 2 had 4000 residents and Durumi 3 had 3000 residents (stratified sampling). Proportionally, calculating $3 \%$ of participants from each stratum is 150,120 and 90. Thereafter, with the help of a research Assistant, simple random sampling was used to select this number of participants from each stratum making a total of 360 selected participants (200 females and 160 males). A validated self-structured questionnaire which was administered with the help of a Research Assistant over a two-week period ( $3 \mathrm{pm}$ to $7 \mathrm{pm}$ Monday to Saturday) was for data collection. This time was chosen to allow the participants who were busy at work to return from work. On the spot collection of the questionnaire was carried out. There was no language barrier as all the participants could speak English. The reliability coefficient of the instrument was $r=$ 
0.8. The instrument was divided into three sections as follows:

Section A: Demographic data of participants which include age, sex, marital status, occupation.

Section B: Questions on the participants' knowledge of cholera

To determine if the participants had knowledge, $70 \%$ of them must answer each question correctly. In all, an average score of correct answers for knowledge questions were judged as follows:

Below 70\% $=$ Poor knowledge

$70-79 \%$ = fairly good knowledge

$80-89 \%=$ Good knowledge

$90-99 \%=$ Very good knowledge

Section C: Questions on the participants' awareness of prevention measures for cholera.

To determine if the participants' awareness of prevention measures, $70 \%$ of them must answer each question correctly. In all, an average score of correct answers for awareness of preventive measures were judged as follows:

Below $70 \%=$ Poor awareness to preventive measures

$70-79 \%=$ fairly awareness to preventive measures

$80-89 \%=$ Good awareness to preventive measures

$90-99 \%=$ Very good awareness to preventive measures

\section{Data analysis}

This was carried out using Statistical Package for the Social Sciences (SPSS) 20. Descriptive statistics such as percentages (\%) and frequency counts were generated and inferential statistics of Chi-square was used to analyze the variables under study, p-value was set at 0.05 significant levels.

Ethical Considerations: An ethical approval to collect data was given by the Health Department of Abuja Municipal Area Council (REF: AMAC/PHC/HSS/71). Informed consent was obtained from the participants ensuring anonymity and absence of coercion.

\section{RESULTS}

However, 330 questionnaires (171 females and 159 males) were finally analyzed (8.4\% attrition); some participants returned questionnaires that were not analyzable at the end of the study.

Table 1 shows the demographic variables of the participants. Gender distribution of the participants shows that majority (171) representing $52 \%$ of the participants were females while 159 of the participants, representing $48 \%$ were males. Also, the distribution of the participants by age group shows that majority of the participants $27 \%$ (89) were within the age group of 26 and 33 years; 18 25 years $(23.9 \%) ; 34-41$ years $(17.9 \%) ; 17.3 \%$ were age range $42-49 ; 10 \%$ were between 50 and 57 years and the least (3.9\%) among them was those within the age range of 58 years and above. The marital status of the participants shows that $163(49.4 \%)$ out of 330 participants were married; $142(43 \%)$ of the participants were single; $17(5.2 \%)$ of the participants were divorced and only 8 of the participants, representing $2.4 \%$ were widowed. The occupation of the participants shows that civil servants were $77(23.3 \%)$, traders $100(30.3 \%)$, students $116(35.2 \%)$ and farmers $37(11.2 \%)$.

Table 2 shows the participants' overall general knowledge of cholera. It answers the first research question. An overall score of $87.4 \% \%$ denotes good general knowledge of cholera. Only the question on the occurrence of cholera in the community was $67 \%$ denotes poor knowledge, all other questions were answered correctly above $70 \%$.

Table 3 also shows the participants' overall awareness of preventive measures of cholera. It answers the second research question. An overall score of $82.8 \%$ denotes good awareness of preventive measures of cholera. However, the last two questions (numbers 13 \& 14) were poorly answered.

\section{Hypotheses testing}

Table 4 shows the analysis for the first hypothesis. The Chi-square result on this table indicates that the chi-square $\left(\mathrm{X}^{2}\right)$ value 76.25 is greater than the table value $11.07\left(\mathrm{X}_{\mathrm{cal}}>\mathrm{X}_{\mathrm{tab}}\right)$, therefore, the null hypothesis which states that there is no significant difference in the mean general knowledge score of cholera between the different age groups is rejected and the alternate hypothesis is accepted: there is a significant difference in the mean general knowledge score of cholera between age groups.

Table 5 shows the analysis for the second hypothesis. The Chi-square result on this table indicates that the chi-square $\left(\mathrm{X}^{2}\right)$ value 12.85 is greater than the table value $11.07\left(\mathrm{X}_{\mathrm{cal}}>\mathrm{X}_{\mathrm{tab}}\right)$, therefore, the null hypothesis which states that 
there is no significant difference in the mean knowledge of preventive measures score between the different age groups is rejected. This shows that there is significant difference in the mean knowledge of preventive measures score between the different age groups.

\section{DISCUSSION}

This descriptive study highlights the knowledge and awareness of preventive measures of cholera among residents of Durumi district, Abuja Municipal Area Council, Abuja, Nigeria. The demographic data shows that more females took part in the study. This is noteworthy because in Nigeria culture, keeping a clean home environment, preparing hygienic and healthy food is almost a sole responsibility of the woman $(19,20)$. Also, Odia and colleagues (21) reported that most of the studies conducted in the western part of the country showed that women and girls display more pro-environmental and eco-friendly behaviour. Therefore, women being more in this study further support these previous studies. With this role performed by women naturally, having them in a good number to ascertain their knowledge and preventive measures of cholera is important in a study like this so that a targeted health education intervention may be given if they lack knowledge that may put them at risk of cholera.

The age distributions of the participants show that over $86 \%$ of the participants were below 50 years of age. This implies that majority of the participants in Durumi community were in their youthful year. It is good to know that there are many relatively young people in Durumi community, which may also imply that the people may be able to work hard to keep their environment clean and also put up community effort to provide clean water for their use. Usually, young people have more of the required knowledge of disease than old people because of their active involvement in social media $(22 ; 23)$. The good number of young people may be an advantage if they are directed to get involved in environmental sanitation to give a face lift to the community. Dan-Nwafor et al. (16) and Nsagha et al. (26) observed that youths in a community can get involved in community and environmental sanitation. The marital status of the residents show that there are many single people in the community (43\%); this further buttress the fact that the unmarried people may have less responsibility and may be able to convert their youthfulness and being single into prevention of cholera by getting more involved in environmental sanitation of the community. The occupation of the people of Durumi reveals that there are many students as well as traders. As earlier pointed out, students are usually abreast of current happenings in any society $(22 ; 23)$. Being youths and students may be the reason why the people were able to answer most of the questions asked correctly. However, it is not certain if they actually have indebt understanding of the correct answers that they gave. However, application of their knowledge to practice is of utmost importance. Efforts need to be made to enlighten them on how to apply their knowledge adequately to prevent future cases of cholera infection. It is possible that the traders (they make up over 30\% in the community) may be contributing negatively to the environment by making the place dirty after the day's business; all these issues call for health education to deepen the application of knowledge of the people.

The first research question that asked if the participants had general knowledge of cholera was answered positively as the participants demonstrated good knowledge of cholera in all the questions asked except one (see Q 10 table 2). The only question they did not appear to answer knowledgeably was about the occurrence of cholera in their community. This is pardonable because they may not know how to differentiate cholera from other diarrhoea diseases. Again, health education may bridge this knowledge gap.

The second research question which also asked about the awareness of preventive measures of the participants was also positively answered (see table 3). Although, the participants demonstrated good awareness, two of the questions were poorly answered demonstrating poor knowledge. The participants were not sufficiently aware that overcrowding and not applying "non-touch technique" in burial of cholera victims can further spread cholera infection (table 3). Olarenwaju (27) reported that in the study of cholera he carried out in Ile-Ife Nigeria, hot spots clusters of cholera cases were seen mainly in areas of very high to high population densities. In the same vein, DanNwafor et al. (16) reported that in a study on cholera carried out in Kwali (FCT, North-central part of Nigeria), cholera infections was termed "disease of poverty" because of its association with overcrowded and unclean environmental condition. This was also observed in Durumi community. Dan-Nwafor et al. (16) had also pointed out the need to apply caution by utilizing the "non-touch technique" in the burial practices 
of cholera victims to avoid the spread of the disease. This is another call for serious health education intervention in the community.

The first hypothesis tested the significant difference in the mean general knowledge score of cholera between the different age groups (see table 4). The result showed that there was a significant difference, the Null hypothesis was rejected. The Chi-square analysis shows that the age group above fifty years old had the least mean score. The younger group (below 50 years) having more knowledge may be from social media use which is commoner in young people $(22 ; 23)$.

This finding of apparent knowledge in the community may be due to the fact that there were many young people in the community that participated in the study. The young people are mostly connected to social media and so may have gotten a lot of information that keep them abreast of knowledge of many diseases including cholera $(22 ; 23)$. Also, there may have been some level of insincerity in the responses given by the participants. However, this apparent knowledge did not appear to have effect in the lifestyle observed among the people. This assertion is supported from previous studies where it was reported that knowledge did not significantly affect practices regarding cholera, because communities where positive knowledge was reported still had cholera incidences from time to time $(21,24)$. In the same vein, Akabanda (25) reported in the study he carried out in Ghana, that satisfactory knowledge does not necessarily translate into good practice. Nsagha (26) also reported that in the study he carried out in Buea Cameroon; that the participants had good knowledge of cholera but poor handling of food predisposed them to cholera. All these reports have established that knowledge should not be seen as a huge success most times. In view of the above, there may also be need for intense training on food handling, environmental hygiene and other issues concerning cholera infection. Health Education may be employed as a vital tool to curtail a reoccurrence of cholera in order to the incidence of the disease.

The second hypothesis tested the significant difference in the mean awareness of preventive measures score of cholera between the different age groups (see table 5). Again, the Chisquare reveals a significant difference in the different age groups concerning their awareness of the preventive measures of cholera. The ages group below 50 years appear to have more awareness (see table 5). This finding again indicates a lack of proper application of knowledge and the need for targeted health education

\section{Pivotal role of health education:}

Health education has been reported in many studies to be a pivotal tool in curtailing the occurrence of cholera infection $(8,13,16,24)$. Therefore, the response given by this study population concerning overcrowdedness further calls for urgent health education for Durumi community in order to further curtail subsequent cholera infection in the community. The health educators should involve Community and religious leaders in social mobilization campaigns. They should ensure that they disseminate health education messages with the use of appropriate media, such as radio, television or newspapers. Health education will also be used to enhance behaviour change by stressing food and environmental hygiene, including the importance of hand wash with soap and water before and after handling food. There is need to use health education to strengthen surveillance system and early warning in places at high risk of cholera outbreak. The use of health education to improve knowledge and prevention of cholera has also been reported by previous studies to be particularly efficacious in reducing the upsurge of cholera (28). Health education intervention is a necessary tool to be arranged for the residents of Durumi to be able to encourage them to put their knowledge of cholera to an effective use.

This study was not without limitations. Some respondents may have over-estimated their actual practices while responding to the questionnaire which might have introduced response bias in the study.

Some respondents with high knowledge score on cholera may have not been truthful about their actual practices; it is possible that some respondents' claims exceeded their actual practices on cholera prevention.

\section{CONCLUSION}

Durumi residents appear to have adequate knowledge of cholera and its prevention, although older age groups appear to lack sufficient knowledge of cholera and its preventive measures. However, targeted health education has been identified as a necessary tool to enhance the application of their knowledge and also to correct some misgivings they have about some preventive factors of cholera. If promptly utilized, Health Education will help to further curtail cholera infection in the community. 
Recommendation: Interventions should be built on health education and improving access to clean water, sanitation, and hygiene (WASH) practices. Individuals and households should be health educated and encouraged to practice basic hygiene behaviors such as proper hand washing and food handling, which can prevent the contraction and spread of many diseases, not just cholera.

Health education will also stress the importance of social mobilization and dissemination of messaging on cholera prevention through several media channels to widely spread the need to maintain and reinforce use of safe drinking water, safe food, good personal hygiene, and adequate sanitation.

Intense Behavior Change Communications (BCC) education should be incorporated through television and radio broadcasts, public announcements declared in market information centers, and house-to-house inspections and sensitizations should also be enforced throughout the community. BCC education is critical in curbing the outbreak of future cholera.

A Multisectoral approach needs to be emphasized and participation encouraged. This would include ensuring proper medical waste management by the State Ministry of Health and access to clean portable water by the Ministry of water resources.

Acknowledgement: The researchers are grateful to the residents of Durumi community for the support received from them in carrying out this research.

Conflicts of interest: The Authors declare that there is no conflict of interest.

\section{REFERENCES}

1. World Health Organization (WHO). Prevention and Control of cholera outbreaks; WHO policy and recommendations. (Internet). 2019 (cited January 17th, 2019). Available from: https://www.who.int/cholera/technical/preventio n/control/en/

2. Elimian $\mathrm{KO}_{2}$ Musah $\mathrm{A}$, Mezue S, Oyebanji $\mathrm{O}$, Yennan S, Jinadu A, et al. Descriptive epidemiology of cholera outbreak in Nigeria, January-November, 2018: implications for the global roadmap strategy. BMC Public Health. 2019; 19(1):1264 - 1274. doi: 10.1186/s12889. 019-7559-6.

3. United Nations International Children's Emergency Fund (UNICEF). Cholera Epidemiology and Response Factsheet Nigeria. 2019, (cited June 6, 2019). Available from:
https://www.unicef.org/cholera/files/UNICEFFactsheet-Nigeria-EN-FINAL.pdf.

4. Harris JB, Larocque RC, Charles RC, Mazumder RN, Khan AI, Bardhan PK. Cholera's western front. Lancet. 2010;376(9757):1961-1965.

5. Harris JB, Larocque RC, Qadri F, Ryan ET, Calderwood SB. Cholera. Lancet. 2012; 379 (9835): 2466-2476. doi: 10.1016/S01406736(12)60436-X.

6. Ali M, Lopez AL, You YA, Kim YE, Sah B, Maskery B, Clemens J. The Global Burden of Cholera. Bulletin of the World Health Organization. 2012; 90:209-218A. doi: 10.2471/BLT.11.093427.

7. Ganesan D, Gupta SS, Legros D. Cholera surveillance and estimation of burden of cholera. Vaccine. 2020; 38 (supplement 1): A13-A17. https://doi.org/10.1016/j.vaccine.2019.07.03.

8. Adagbada A, Francisca ON, Solayide AA, Niemogha MT, Akitoye OC. Cholera Epidemiology in Nigeria: An overview. Pan Africa Medical Journal.2012; 1(3), 37-42.

9. Mengel MA, Delrieu I, Heyerdahl L, Gessner BD. Cholera outbreaks in Africa. Curr Top Microbiol Immunol. 2014; 379:117-44. doi: $10.1007 / 822014369$.

10. United Nations International Children Education Fund (UNICEF). CHOLERA EPIDEMIOLOGY AND RESPONSE FACTSHEET NIGERIA. (Internet). 2019. Available from https://www.unicef.org/cholera/files/UNICEFFactsheet-Nigeria-EN-FINAL.pdf

11. Ivers LC. Advancing Control of Cholera in the Interest of the Most Vulnerable in our Global Society. The Journal of Infectious Diseases. 2018; (Issue suppl_3): S135-S136. doi: https://doi.org/10.1093/infdis/jiy458.

12. National Centre for Disease Control (NCDC). An update of Cholera outbreak in Nigeria. Internet. 2019 (cited August 2, 2019) Available from https://ncdc.gov.ng/diseases/sitreps/?cat=7\&na me $=$ An $\% 20$ update $\% 20$ of $\% 20$ Cholera $\% 20$ outbr eak $\% 20 \mathrm{in} \% 20$ Nigeria.

13. Denue BA, Akawu CB, Kwayabura $\mathrm{SA}_{\llcorner}$Kida I. Low case fatality during 2017 cholera outbreak in Borno State, North Eastern Nigeria. Ann Afr Med. 2018 ; 17 (4): 203-209. d o i : 10.4103/aam.aam 6617.

14. World Health Organization (WHO). Nigeria Cholera Outbreak June 2017. Internet. 2019 (cited July 4, 2019). Available from https:www.who.int/csr/don 12-july-2017cholera-nigeria/en/

15. Idoga PE, Toycan M, Zayyad MA. Analysis of Factors Contributing to the Spread of Cholera in Developing Countries. Eurasian J Med. 2019; 51 ( 2 ) : $121-127 . \quad$ d o i : 10.5152/eurasianjmed.2019.18334.

16. Dan-Nwafor CC, Ogbonna U, Onyiah P, Gidado S, Adebobola B, Nguku P, Nsubuga P. A cholera outbreak in a rural north central Nigerian community: an unmatched case-control study. 
BMC Public Health. 2019; 19, 112. https://doi.org/10.1186/s12889-018-6299-3.

17. National Population Commission (NPC). Population estimate. Internet. 2018 (cited January 6, 2018). Available from https://www.nationalpopulation.gov.ng

18. Abuja City Population. Internet. 2019 (cited August 5, 2019). Available from https://www.citypopulation.de/php/nigeriaadmin.php?adm1id=NGA015.

19. Ngwa MC, Young A, Liang S, Blackburn J, Mouhaman A, Morris JG Jr. Cultural influences behind cholera transmission in the Far North Region, Republic of Cameroon: a field experience and implications for operational level planning of interventions. Pan Afr Med J. 2017; $28: 311-320 . \quad$ d o i : 10.11604/pamj.2017.28.311.13860.

20. Gama A, Kabwe P, Nanzaluka F, Langa N, Mutale L, Mwanamoonga L, et al. Cholera Outbreak in Chienge and Nchelenge Fishing Camps, Zambia, 2017. Health Press Zambia Bull. 2017; 2(1): 1219.

21. Odia J, Odia AA. Gender Differences and Environmental Friendliness among Secondary School Students in Benin Metropolis, Nigeria. Indonesian Journal of Contemporary Management Research. 2019; 1 (1): 1 - 14. doi: 10.33455/ijcmr.v1i1.82.

22. Leist AK. Social Media Use of Older Adults: A Mini-Review. Gerontology 2013; 59:378-384. https://doi.org/10.1159/000346818.

23. Ali A, Iqbal A, Iqbal K. Effects of Social Media on Youth: A Case Study in University of Sargodha. Int. J. Adv. Res. 2016; 4(11): 369-372.
http://dx.doi.org/10.21474/IJAR01/2093.

24. Childs L, François J. Choudhury A, Wannemuehler K, Dismer A, Hyde TB, et al. Evaluation of Knowledge and Practices Regarding Cholera, Water Treatment Hygiene, and Sanitation before and after an Oral Cholera Vaccination Campaign-Haiti, 2013-2014. Am J Trop Med Hyg. 2016; 95(6): 1305-1313. doi: 10.4269/ajtmh.16-0555.

25. Akabanda F, Hlortsi EH, Owusu-Kwarteng J. Food safety knowledge, attitudes and practices of institutional food-handlers in Ghana. $B M C$ Public Health. 2017; 17:40 - 49. https://doi.org/10.1186/s12889-016-3986-9

26. Nsagha DS, Atashili J, Fon PN, Tanue EA, Ayima $\mathrm{CW}$, Kibu OD. Assessing the risk factors of cholera epidemic in the Buea Health District of Cameroon. BMC Public Health. 2015; 15: 1-7. Article number: 1128. doi 10.1186/s12889-0152485-8.

27. Olanrewaju OE, Adepoju KA. Geospatial Assessment of Cholera in a Rapidly Urbanizing Environment. Journal of Environmental and Public Health. 2017; Article ID 6847376:1- 8. https://doi.org/10.1155/2017/6847376.

28. Wahed T, Kaukab SST, Saha NC, Khan IA, Khanam F, Chowdhury, et al. Knowledge of, attitudes toward, and preventive practices relating to cholera and oral cholera vaccine among urban high-risk groups: findings of a cross-sectional study in Dhaka, Bangladesh. BMC Public Health. 2013; 13:242 -253. http://www.biomedcentral.com/1471$2458 / 13 / 242$. 
Table 1: Demographic Data of the Participants

\begin{tabular}{lcc}
\hline Item & $\begin{array}{l}\text { Frequency } \\
(\mathbf{N = 3 3 0 )}\end{array}$ & $\begin{array}{l}\text { Percentages } \\
(\mathbf{\%})\end{array}$ \\
\hline Gender & 159 & 48 \\
Male & 171 & 52 \\
Female & & \\
Age (in years) & 79 & 23.9 \\
18-25 & 89 & 27 \\
26-33 & 59 & 17.9 \\
34-41 & 57 & 17.3 \\
42-49 & 33 & 10 \\
50-57 & 13 & 3.9 \\
58 \& above & & \\
Marital Status & 142 & 43 \\
Single & 163 & 49.4 \\
Married & 17 & 5.2 \\
Divorced & 8 & 2.4 \\
Widowed & & \\
Occupation & 77 & 23.3 \\
Civil Servant & 100 & 30.3 \\
Trading & 116 & 35.2 \\
Students & 37 & 11.2 \\
Farming & & \\
\hline
\end{tabular}

Table 2: Item analysis of participants overall general knowledge of cholera $(\mathbf{N}=\mathbf{3 3 0})$ (Research Question 1: Are Durumi residents generally knowledgeable about cholera?)

\begin{tabular}{|c|c|c|c|c|c|c|}
\hline $\mathbf{S} / \mathbf{N}$ & Items & Yes & No & \% Yes & $\begin{array}{l}\% \\
\text { No }\end{array}$ & $\begin{array}{l}\text { Accept } \\
\text { Knowledge }(\checkmark)\end{array}$ \\
\hline 1 & Have you ever heard about cholera? & 321 & 9 & 97.3 & 2.7 & $\checkmark$ \\
\hline 2 & Can you get cholera from drinking water? & 309 & 21 & 93.6 & 6.4 & $\checkmark$ \\
\hline 3 & Is cholera caused by witchcraft? & 15 & 315 & 4.5 & 95.5 & $\checkmark$ \\
\hline 4 & Can you get cholera from food? & 302 & 28 & 91.5 & 8.5 & $\checkmark$ \\
\hline 5 & Does cholera cause death? & 300 & 30 & 90.9 & 9.1 & $\checkmark$ \\
\hline 6 & Can you get cholera from wind (breeze or air)? & 69 & 261 & 20.9 & 79.1 & $\checkmark$ \\
\hline 7 & Can one get cholera from body contact? & 7 & 323 & 2.1 & 97.9 & $\checkmark$ \\
\hline 8 & Can one be cured of cholera? & 299 & 31 & 90.6 & 9.4 & $\checkmark$ \\
\hline 9 & $\begin{array}{l}\text { Can cholera be transferred from one person to } \\
\text { another? }\end{array}$ & 287 & 43 & 87 & 13 & $\checkmark$ \\
\hline 10 & $\begin{array}{l}\text { Is cholera a common disease in your } \\
\text { community? }\end{array}$ & 221 & 109 & 67 & 33 & Poor knowledge \\
\hline 11 & $\begin{array}{l}\text { Do you know how cholera is contacted? } \\
\text { Overall Percentage general knowledge of } \\
\text { cholera }\end{array}$ & 233 & 97 & 70.6 & 29.4 & $\begin{array}{l}\checkmark \\
* 87.4 \%\end{array}$ \\
\hline
\end{tabular}


Table 3: Participants overall awareness of preventive measures of cholera (330)

Research Question 2: Is there an overall awareness of cholera among Durumi residents?

\begin{tabular}{|c|c|c|c|c|c|c|c|c|}
\hline $\mathbf{S} / \mathbf{N}$ & Items & $\mathbf{S A}$ & $\mathbf{A}$ & $\mathbf{D}$ & SD & $\begin{array}{l}\% \\
\text { Agree }\end{array}$ & $\begin{array}{l}\% \\
\text { Disagree }\end{array}$ & $\begin{array}{l}\text { Accept } \\
\text { Awareness } \\
(\checkmark)\end{array}$ \\
\hline 1 & Cholera is caused by air & 12 & 32 & 174 & 112 & 13.3 & 86.7 & $\checkmark$ \\
\hline 2 & Witchcraft is the reason for cholera & 3 & 8 & 201 & 118 & 3.3 & 96.7 & $\checkmark$ \\
\hline 3 & $\begin{array}{l}\text { Open defecation contribute to cholera } \\
\text { outbreak }\end{array}$ & 154 & 144 & 18 & 14 & 90.3 & 9.7 & $\checkmark$ \\
\hline 4 & $\begin{array}{l}\text { Contaminated water with cholera organism } \\
\text { is the source of cholera }\end{array}$ & 79 & 183 & 38 & 30 & 79.4 & 20.6 & $\checkmark$ \\
\hline 5 & Covering of food helps prevent cholera & 87 & 199 & 34 & 10 & 86.7 & 13.3 & $\checkmark$ \\
\hline 6 & $\begin{array}{l}\text { Going to toilet without washing your hand } \\
\text { causes cholera }\end{array}$ & 69 & 223 & 29 & 9 & 88.5 & 11.5 & $\checkmark$ \\
\hline 7 & $\begin{array}{l}\text { Poor environmental sanitation contribute } \\
\text { greatly to cholera }\end{array}$ & 58 & 209 & 52 & 11 & 80.9 & 19.1 & $\checkmark$ \\
\hline 8 & $\begin{array}{l}\text { Food contaminated by fly is the source of } \\
\text { cholera }\end{array}$ & 88 & 217 & 19 & 6 & 92.4 & 7.6 & $\checkmark$ \\
\hline 9 & $\begin{array}{l}\text { Improper use and maintenance of toilet } \\
\text { (latrine) can cause cholera outbreak }\end{array}$ & 92 & 221 & 15 & 2 & 94.8 & 5.2 & $\checkmark$ \\
\hline 10 & $\begin{array}{l}\text { Boiling of water before drinking help reduce } \\
\text { the risk of cholera infection }\end{array}$ & 82 & 201 & 34 & 13 & 85.8 & 14.2 & $\checkmark$ \\
\hline 11 & Use of safe water reduce cholera outbreak & 89 & 210 & 25 & 6 & 90.6 & 9.4 & $\checkmark$ \\
\hline 12 & $\begin{array}{l}\text { Lack of personal hygiene contribute to } \\
\text { cholera }\end{array}$ & 101 & 189 & 26 & 15 & 87.9 & 12.1 & $\checkmark$ \\
\hline 13 & Overcrowding can spread cholera infection & 52 & 94 & 89 & 95 & 44.2 & 55.8 & $\begin{array}{l}\text { Poor } \\
\text { knowledge }\end{array}$ \\
\hline 14 & $\begin{array}{l}\text { Burial practices for a cholera victim must be } \\
\text { of "non-touch technique" to prevent the } \\
\text { spread of cholera }\end{array}$ & 99 & 80 & 88 & 63 & 54.2 & 45.8 & $\begin{array}{l}\text { Poor } \\
\text { knowledge }\end{array}$ \\
\hline & $\begin{array}{l}\text { Overall Percentage Awareness of } \\
\text { prevention of cholera }\end{array}$ & & & & & & \multicolumn{2}{|c|}{ * $82.8 \%$} \\
\hline
\end{tabular}

Key: SA \& A = \% Agree; D \& SD = \% Disagree

*Note: All correct answer scores divide by $14=82.8 \%$

An overall score of $82.8 \%$ denotes good awareness of preventive measures of cholera

Table 4: Chi-Square Summary of Participants on Knowledge of Cholera

\begin{tabular}{lccccc}
\hline $\begin{array}{c}\text { Variable } \\
\text { (Age) }\end{array}$ & $\begin{array}{c}\text { Knowledge of Cholera } \\
\text { Yes }\end{array}$ & No & Total & $\begin{array}{c}\text { Chi-Square } \\
\text { Value }\end{array}$ & P-value \\
\hline $18-25$ & 39 & 13 & 52 & 76.25 & 11.07 \\
$26-33$ & 38 & 25 & 63 & & \\
$34-41$ & 40 & 19 & 59 & & \\
$42-49$ & 35 & 23 & 58 & & \\
$50-57$ & 34 & 15 & 49 & & \\
58 \& above & 29 & 20 & 49 & & \\
Total & $\mathbf{2 1 5}$ & $\mathbf{1 1 5}$ & $\mathbf{3 3 0}$ & & \\
\hline
\end{tabular}

H01: There is no significant difference in the percentage general knowledge score of cholera between the different age groups.

Table 5: Chi-Square Summary of Participants on Preventive Measures

\begin{tabular}{lccccc}
\hline $\begin{array}{c}\text { Variable } \\
\text { (Age) }\end{array}$ & $\begin{array}{c}\text { Preventive Measures } \\
\text { Agree }\end{array}$ & Disagree & Total & $\begin{array}{c}\text { Chi-Square } \\
\text { Value }\end{array}$ & P-value \\
\hline $18-25$ & 42 & 14 & 56 & 12.85 & 11.07 \\
$26-33$ & 33 & 15 & 48 & & \\
$34-41$ & 40 & 18 & 58 & & \\
$42-49$ & 41 & 23 & 64 & & \\
$50-57$ & 32 & 31 & 63 & & \\
58 \& above & 26 & 15 & 41 & & \\
Total & $\mathbf{2 1 4}$ & $\mathbf{1 1 6}$ & $\mathbf{3 3 0}$ & & \\
\hline
\end{tabular}

$\mathbf{H}_{\mathbf{0 2}}$ : There is no significant difference in the percentage awareness of preventive measures score between the different age groups. 